\title{
Estimation of Haematological Changes in Crossbred Cattle Infected with Theileria annulata
}

\author{
Ankit Nagar, Rajeev Ranjan Kumar* and Stuti Vatsya
}

Department of Veterinary Parasitology, College of Veterinary and Animal Sciences, G.B. Pant University of Agriculture and Technology, Pantnagar, Uttarakhand, India

*Corresponding author

\section{A B S T R A C T}

Keywords

Theileria annulata, cattle, haematology

Article Info

\section{Accepted:}

12 April 2021

Available Online:

10 May 2021
Theileria annulata is an important tick-borne haemoprotozoan organism affecting dairy animals worldwide including India. It causes enormous economic losses in cattle and buffaloes in terms of reduced milk production, increased infertility and high mortality rate. The present study was undertaken to estimate the various haematological changes in cattle infected with $T$. annulata. Haematological examination revealed a significant $(\mathrm{P}<0.05)$ decrease in haemoglobin concentration $(6.28 \pm 0.42 \mathrm{~g} \%)$, packed cell volume $(19.14 \pm 1.20 \%)$, total erythrocytic count $\left(3.98 \pm 0.21 \times 10^{6} / \mu \mathrm{l}\right)$ and increase in total leucocyte count $\left(9.31 \pm 0.37 \times 10^{3} / \mu \mathrm{l}\right)$ were recorded in infected animals. However, it was $10.29 \pm 0.38 \mathrm{~g} \%, 31.19 \pm 1.09 \%$, $6.02 \pm 0.19 \times 10^{6} / \mu 1$ and $8.37 \pm 0.24 \times 10^{3} / \mu 1$, respectively in infected group. Significant $(\mathrm{P}<0.05)$ lymphopenia $(51.90 \pm 4.30 \%)$ and neutrophilia $(36.00 \pm 4.89 \%)$ were observed in infected cattle. However, differential leucocytes count revealed $60.90 \pm 1.52 \%$ lymphocytes and $34.80 \pm 1.58 \%$ neutrophils in control animals. The increase in monocytes $(5.50 \pm 1.00 \%)$ and eosinophils $(6.60 \pm 2.50 \%)$ were observed in infected cattle as compared with uninfected control monocytes $(1.80 \pm 0.40 \%)$ and eosinophils $(2.50 \pm 0.57 \%)$. A decrease in MCV (48.04 $\pm 1.81 \mathrm{fl})$ and MCH $(15.73 \pm 0.54$ pg) were observed in infected group as compared to control (MCV-51.81 $\pm 0.77 \mathrm{fl}$ and $\mathrm{MCH} 17.08 \pm 0.26 \mathrm{pg}$ ) which revealed microcytic RBC's and low average quantity of haemoglobin present in single erythrocyte, respectively. However, no changes was observed in MCHC $(32.78 \pm 0.37 \mathrm{~g} \%)$ in infected group.

\section{Introduction}

Theileria annulata is an apicomplexan pleomorophic haemoprotozoan organism found in lymphocytes and erythrocytes for completion of their life cycle in mammalian hosts. The organism causes Bovine Tropical Theileriosis in tropical and subtropical region of the country. In India the disease causes a serious problem in exotic and cross bred cattle (Kohli et al., 2014). The prevalence of $T$. annulata has been reported from different 
geographical regions of India including Uttarakhand by the several workers (Rialch et al., 2014; Maharana et al., 2016; Kariyappa et al., 2017 and Acharya et al., 2017; Arun et al., 2019). T. annulata causes enormous economic losses in cattle and buffaloes in terms of reduced milk production, increased infertility and high mortality rate. The assessment of economic losses due to theielriosis has been reported worldwide including India. Devendra (1995) estimated an annual loss of US $\$ 800$ million in India. The early diagnosis of the disease is based on blood smear examination but sometimes organism may not be detected. However, haematological changes give indication of the disease which is helpful to start early treatment and also prevent death of the animals (Modi and Bhadesiya, 2004). Keeping in view these facts, the present study was conducted to estimate the haematogical changes in cattle infected with $T$. annulata.

\section{Materials and Methods}

A total of 524 blood samples of cattle were collected from the villages of various tehsils of district Udham Sing Nagar, Uttarakhand and Teaching Veterinary Clinical Complex, College of Veterinary and Animal Sciences, Pantnagar during July, 2017 to June, 2018. Microscopically thin blood smear were examined using Giemsa stain for the demonstration of organism. A total of 10 crossbred cattle found positive and 10 found negative for $T$. annulata were selected for the estimation of haematological parameters and grouped as GI infected and GII (uninfected control), respectively. Analysis of various haematological parameters viz. haemoglobin $(\mathrm{Hb})$, total erythrocyte count (TEC), total leukocyte count (TLC), differential leukocyte count (DLC), packed cell volume (PCV), mean corpuscular volume (MCV), mean corpuscular haemoglobin $(\mathrm{MCH})$, mean corpuscular haemoglobin concentration (MCHC) were estimated as per method described by Jain, 1964. Statistical analysis of data was performed by Student ' $t$ ' test described by Snedecor and Cochran (1994).

\section{Results and Discussion}

The mean haematological value of cattle infected with $T$. annulata is presented in Table 1. In the present study, increased total leukocyte counts $(9.31 \pm 0.37)$ was recorded as compared to uninfected control $(8.37 \pm 0.24)$. The finding is in consonance with the findings of Modi et al., 2015; Ganguly et al., 2015 and Goyal et al., 2017. However, after increase in TLC, significant decrease within several days in Theileria affected cattle was recorded by Sandhu et al., (1998).

Significant $(\mathrm{P}<0.05)$ lymphopenia $(51.90 \pm 4.30$ $\%)$ and neutrophilia $(36.00 \pm 4.89 \%)$ were observed in infected cattle. However, differential leucocytes count revealed $60.90 \pm 1.52 \%$ lymphocytes and $34.80 \pm 1.58 \%$ neutrophils in control animals. Similar findings were also reported by Tehrani et al., 2013 and Goyal et al., 2017. In contrast to present study, Aulakh et al., (1998) observed lymphocytosis and neutropenia in infected cattle, while Omar et al., (2002) found lymphocytopenia and neutropenia. Muraleedharan et al., (2005) found lymphocytosis and neutrophilia in infected cattle. In the present study, the increase in monocytes $(5.50 \pm 1.00 \%)$ and eosinophils $(6.60 \pm 2.50 \%)$ were observed in infected cattle while it was as recorded $1.80 \pm 0.40 \%$ and $2.50 \pm 0.57 \%$, respectively in uninfected control animals.

A decrease in MCV $(48.04 \pm 1.81 \mathrm{fl})$ and $\mathrm{MCH}$ $(15.73 \pm 0.54 \mathrm{pg})$ were observed in infected group as compared to control (MCV$51.81 \pm 0.77 \mathrm{fl}$ and $\mathrm{MCH} 17.08 \pm 0.26 \mathrm{pg}$ ) which revealed microcytic RBC's and low average quantity of haemoglobin present in single erythrocyte, respectively. 
Table.1 Mean haematological values in cattle infected with Theileria annulata and control animals

\begin{tabular}{|c|c|c|c|c|}
\hline S. No. & Parameters & Infected & Control & 't' value \\
\hline $\mathbf{1}$ & $\mathrm{Hb} \mathrm{g \%}$ & $6.28 \pm 0.42$ & $10.29 \pm 0.38$ & -7.43 \\
\hline $\mathbf{2}$ & $\mathrm{PCV}(\%)$ & $19.14 \pm 1.20$ & $31.19 \pm 1.09$ & -7.78 \\
\hline $\mathbf{3}$ & TEC $\left(\times 10^{6} / \mu \mathrm{l}\right)$ & $3.98 \pm 0.21$ & $6.02 \pm 0.19$ & -7.43 \\
\hline $\mathbf{4}$ & $\mathrm{MCV}(\mathrm{fl})$ & $48.04 \pm 1.81$ & $51.81 \pm 0.77$ & $-2.01^{*}$ \\
\hline $\mathbf{5}$ & $\mathrm{MCH}(\mathrm{pg})$ & $15.73 \pm 0.54$ & $17.08 \pm 0.26$ & -2.36 \\
\hline $\mathbf{6}$ & $\mathrm{MCHC}(\mathrm{g} \%)$ & $32.78 \pm 0.37$ & $32.98 \pm 0.25$ & $-0.44^{*}$ \\
\hline $\mathbf{7}$ & TLC $\left(\times 10^{3} / \mu \mathrm{l}\right)$ & $9.31 \pm 0.37$ & $8.37 \pm 0.24$ & 2.19 \\
\hline $\mathbf{8}$ & Neutrophil $(\%)$ & $36.00 \pm 4.89$ & $34.80 \pm 1.58$ & $0.25^{*}$ \\
\hline $\mathbf{9}$ & Lymphocyte $(\%)$ & $51.90 \pm 4.30$ & $60.90 \pm 1.52$ & -2.12 \\
\hline $\mathbf{1 0}$ & Monocyte $(\%)$ & $5.50 \pm 1.00$ & $1.80 \pm 0.40$ & 3.58 \\
\hline $\mathbf{1 1}$ & Eosinophil $(\%)$ & $6.60 \pm 2.50$ & $2.50 \pm 0.57$ & $1.68^{*}$ \\
\hline
\end{tabular}

However, no changes was observed in MCHC $(32.78 \pm 0.37 \mathrm{~g} \%)$ in infected group as compared to control $(32.98 \pm 0.25 \mathrm{~g} \%)$ which clearly indicated that $\mathrm{RBCs}$ were normochromic in animals (Ugalmugle et al., 2010). Hence, infected cattle had suffered with microcytic normochromic anaemia.

The reduction in $\mathrm{Hb}(6.28 \pm 0.42)$, $\mathrm{PCV}$ $(19.14 \pm 1.20)$ and TEC $(3.98 \pm 0.21)$ values were observed in infected cattle which could be attributed to intravascular haemolysis by piroplasms of $T$. annulata which infects and replicate in erythrocytes.

The erythrophagocytosis also favours the reduction of $\mathrm{Hb}, \mathrm{PCV}$ and TEC and it may be immune mediated. The high parasitemia and low RBC count is ascribed to the removal of infected RBCs by spleen and liver and these variations were consistent with the finding of Qayyum et al., 2010; Tehrani et al., 2013 and Bahera, 2016. Leucocytosis occurs due to proliferation of lymphocytes and leucopenia is not a characteristic feature of $T$. annulata (Modi et al., 2015). Lymphopenia may occur due to lymphoid hyperplasia followed by exhaustion of the lymphoid tissues in later stage of infection as observed in the present study (Soulsby, 1982).
Haematological changes in cattle infected with $T$. annulata revealed lymphopaenia and neutrophilia. The increase in monocytes and eosinophils were observed in infected cattle as compared with uninfected control. A decrease in MCV was observed in infected group which revealed microcytic RBCs and low average quantity of haemoglobin present in single erythrocyte, respectively.

\section{References}

Acharya, A. P., Panda, S. K. and Prusty, B. K. 2017. Diagnosis and confirmation of Theileria annulata infection in cattle in Odisha, India. J. Entomol. Zool. Stud., 5(4): 1543-1546.

Arun Raj, M. R., Vatsya, S. and Kumar, R. R. 2019. Prevalence of bovine tropical Theileriosis in sub- Himalayan region of northern India. Indian J.Anim. Sci., 79(7): 728-37.

Aulakh, G. S. and Singla, L. D. 2006. Clinicohemtobiochemical observations on bovines naturally infected with Theileria annulata. J. Vet. Parasitol., 20: 49-52.

Bahera, S. C. 2016. Haematological and biochemical alteration in theileriosis affected cattle. M.V.Sc. Thesis 
submitted to Orissa University of Agriculture \& Technology. Pp. 40

Devendra, C. (1995). In Global Agenda for Livestock Research, EDS, ILRI, Nairobi., Pp. 41-48.

Ganguly, A., Bhanot, V., Bisla, R. S., Ganguly, I., Singh, H. and Chaudhri, S.S. 2015.

Hematobiochemical alterations and direct blood polymerase chain reaction detection of Theileria annulata in naturally infected crossbred cows. Vet. World., 8(1): 24-28.

Goyal, P., Chahar, A., Tanwar, R. K. and Fakhruddin 2017. ClinicoPhysiological and Haematological studies in cattle-calves naturally infected with Theileria annulata by nested PCR. Bull. Env. Pharmacol. Life Sci., 6(3): 39-44

Jain, N.C. 1986. Schalm's Veterinary Hematology (No. Edition 4). Lea \& Febiger.

Kohli, S., Atheya, U. K. and Thapliyal, A. (2014). Prevalence of theileriosis in crossbred cattle: its detection through blood smear examination and polymerase chain reaction in Dehradun district, Uttarakhand, India. Vet. World, 7(3): 168-171.

Maharana, B. R., Kumar, B., Prasad, A., Patbandha, T. K., Sudhakar, N. R., Joseph, J. P. and Patel, B. R. 2016. Prevalence and assessment of risk factors for haemoprotozoan infections in cattle and buffaloes of South-West Gujarat, India. Indian J. Anim. Res., 50 (5): 733-739.

Modi, D. V and Bhadesiya, C. M. 2014. Tickborne Theileria annulata in dairy cows: A short notes for field vets. Int. J. Life Sci. Res., 2(4): 127-129.

Modi, D. V., Bhadesiya, C. M. and Mandali, G. C. 2015. Hematobiochemical Changes in Crossbred Cattle Infected with Theileria annulata in
Banaskantha District of Gujarat. Int. J. Sci. Res. Pub., 5: 1.

Kariyappa, P. R., Ravindran, R., Nimisha, M., Mallappa, B., Amrutha, Prashant Somalingappa Kurbet, A. M. S., Kumar, K. G. A., Varghese, A., Deepa, C. K. and Dinesh, C. N. 2017. Prevalence of Bovine Babesiosis and Theileriosis in Kerala, India. Int. J. Cuurr. Microbiol. Appl. Sci., 6(8): 2310-2314.

Muraleedharan, K., Ziauddin, K. S., Hussain, P. M., Puttabyattappa, R. and Seshadri, S. J. 2005. Hematological observation on Theileria annulata infection in cattle and buffaloes. J. Vet. Parasitol., 19: 71-72.

Omar, O. H., El-Malik, K. H., Mahmoud, O. M., Haroun, E. M., Hawas, A., Sweeney, D. and Magzoub, M. 2002. Hematological profiles in purebred cattle naturally infected with Theileria annulata in Saudi Arabia. Vet. Parasitol., 107: 161-168.

Qayyum, A., Farooq, U., Samad, H. A. and Chauhdry, H. R. (2010) Prevalence, clinico-therapeutic and prophylactic studies on Theileriosis in district Sahiwal (Pakistan). J. Anim. Plant Sci., 20(4): 266-270.

Rialch A., Vatsya, S. and Kumar, R. R. 2013. Prevalence of some blood parasites in large ruminants of Tarai region of Uttarakhand. Pantnagar J. Res., 11(2): 315-316.

Sandhu, G. S., Grewal, A. S., Singh, A., Kondal, J. K., Singh, J. and Brar, R. S. 1998. Haematological and biochemical studies on experimental Theileria annulata infection in crossbred calves. Vet. Res. Commun., 22: 347-355.

Snedecor, G. W. and Cochran, W. G. 1994. Statistical methods. $6^{\text {th }}$ edn. Oxford and IBH publishing company, Calcutta. 
Soulsby, E. J. L. 1982. Helminths, Arthropods and Protozoa of domesticated animals. $7^{\text {th }}$ edn.London, $\quad$ English language book society and Baillieret. pp: 381.

Tehrani, A. A., Hosseini, E. and Bahrami, A. M. (2013). Biochemical, Hematological studies in cattle naturally infected with Theileria annulata. Bull. Env. Pharmacol. Life Sci., 2(9): 07-10

Ugalmugle, S. S., Jayraw, A. K. and Gatne, M. L. 2010. Prevalence and clinical pathology of bovine tropical theileriosis in crossbred population of Ahmednagar district of Maharashtra. J. Vet. Parasitol., 24(2): 141-145.

\section{How to cite this article:}

Ankit Nagar, Rajeev Ranjan Kumar and Stuti Vatsya. 2021. Estimation of Haematological Changes in Crossbred Cattle Infected with Theileria annulata. Int.J.Curr.Microbiol.App.Sci. 10(05): 27-31. doi: https://doi.org/10.20546/ijcmas.2021.1005.006 